\title{
Firm Size and Work-Related Training: New Evidence on Incidence, Intensity, and Training Type from Australia
}

\author{
C. Jeffrey Waddoups* \\ Department of Economics \\ University of Nevada, Las Vegas \\ Las Vegas, NV 89154-6005 \\ Phone: 702-895-3497 \\ Fax: 702-895-1354 \\ Email: Jeffrey.Waddoups@unlv.edu
}

\begin{abstract}
This study examines the relationship between firm size and structured work-related training by analyzing data from the 2001 installment of the Australian Bureau of Statistics' Survey of Education and Training. The results show a positive correlation between the probability of training and firm size for both male and female workers. A similar positive correlation between the intensity of training and firm size is also evident. Although the incidence of training is roughly comparable for male and female workers, males tend to train significantly more hours than their female counterparts. The findings also indicate that much less training occurs in firms with fewer than 10 workers, especially in health and safety, management and professional, and technical and paraprofessional training. Such results suggest that research on the size-training effect using firm- or establishment-level data, which generally focus only on firms with 20 or more employees, cannot detect an important source of the potential training deficit.
\end{abstract}

*Professor Waddoups is also adjunct Associate Professor of Management at Griffith University. 


\section{Introduction}

Work-related training plays a significant role in human capital formation in advanced economies. In spite of its important role, research on the determinants of training remains deficient, in part because of the lack of appropriate data. One particularly under-researched topic within the training literature is the relationship between employer size and substantive types of work-related training (i.e. computing, health and safety, management/professional, etc.). Although the positive relationship between size and the incidence and intensity of training has become well-established, there has been much less work on how employer size is linked with the kinds of training firms generally provide, simply because the data sets analysts use to study training often do not observe the substance of training courses.

Another common deficiency in the size-training literature lies in the failure to observe training in very small firms (say firms with fewer than 10 workers). This problem is not trivial. In the U.S. approximately 16 percent of employment is attributable to firms with nine or fewer workers (Butani et al. 2006). Similarly, the figure for Australia is approximately 15 percent of the workforce. ${ }^{1}$ One source of the deficiency is that research focusing specifically on the size-training effect generally has been conducted using data from firm- or establishment-level surveys, which generally exclude smaller firms altogether from their sampling frames. Lynch and Black (1998) for example, explored the size-training issue with data that limited its sample to firms with 20 or more employees, which is typical of such research (also see Frazis, Gittleman and

\footnotetext{
${ }^{1}$ This figure was computed from the Survey of Education and Training data used to conduct the analysis in this study.
} 
Joyce 2000 and Osterman 1995). To the extent that training behavior differs in very small firms compared to their larger counterparts, research using this kind of data will fail to fully capture the economy's training experience, and thus will not observe a potentially significant source of a training deficit that may exist.

Another source of the failure to capture training experience in very small firms arises even when the analyst uses individual-level data that does not exclude very small firms. In such data sets, the smallest size category often combines very small firms with slightly larger firms. For example, the smallest firm-size category in Survey of Program Participation (SIPP), an individual-level data set from the U.S. containing training variables, is fewer than 25 workers. If the experience in very small firms differs significantly from that of their slightly larger counterparts, then the source and nature of a potential training deficit will, again, be missed.

Still another issue arising from the data commonly used to address size-training effects is that some individual-level data sets categorize employer size by assigning a relatively small lower class limit for the largest size category. This has the effect of combining firms together with dissimilar training behavior at the upper end of the size spectrum. For example, consider that the largest firm-size category in the SIPP is 100+ workers. Similarly, most of the installments of the Survey of Education and Training (SET), a large nationally representative survey of training experience in Australia used for the present study, also uses the ' $100+$ ' firm size category. To the extent that firms employing 100 workers exhibit significantly different training behavior than firms employing 1,000 workers, the analysis using such data has the potential to not capture differences in training experience among medium-sized and larger firms. 
The purpose of the present study is to further explore the relationship between employer size and work-related training using an individual-level data set that allows for an examination of size-training effects for different substantive kinds of training, while also observing a wider range of firms sizes, ranging from very small (less than 10 employees) to large (1000+ employees). The data were obtained from the Australian Bureau of Statistics' (ABS) 2001 installment of the SET, a quadrennial survey of a large random sample of working-aged Australians. The SET gathers extraordinarily detailed information relating to training at work, as well as details on other human capital investments, the size of employers, and other variables generally controlled for in labor market analyses. The study is also unique because it is the first to examine the size/training-type issue in a multivariate setting using individual-level data. ${ }^{2}$ Finally, the research adds to the literature by updating and extending Miller's (1994) comparison of size-training effects by gender.

\section{Previous Research}

Empirical research has clearly shown that an employer's size affects labor market outcomes, such as wages, fringe benefits, and turnover (e.g. Brown and Medoff 1989; Oi and Idson 1999; Troske 1999). Studies from the U.K., U.S., and Canada have also documented the relationship between employer size and training, although the findings are often in the context of assessing other determinants of training such as gender,

\footnotetext{
${ }^{2}$ As previously indicated, Lynch and Black (1998) addressed the relationship between employer size and training types using establishment-level data.
} 
educational attainment, or union status. For example, Green, Machin and Wilkinson (1999) study the union-training effect using British firm-level data from the Employers' Manpower and Skills Practices Survey from 1993. They find a statistically significant and increasingly higher probability of training as firms' sizes increase. Notably, the study did not observe the substance of training and the survey's sampling frame only includes firms with 25 or more employees, with the highest category being 1,000+ workers.

In another study focusing on Britain, Booth (1991) uses individual-level data from the British Social Attitudes Survey of 1987, finding that female workers in British firms with 25 or more workers are more likely to engage in job training. Although the size effect is positive for male workers, it is not statistically significant. This is an example of a study that observes individuals with very small employers (say fewer than 10 workers) combined with those employed in slightly larger firms (between 10 and 24 workers). In a more recent study, Green and Lemieux (2007) also combine small and very small firms together when they use individual-level data from Canada to study the relationship between unions and training. They control for firm-size, and not surprisingly, find a lower propensity to train in smaller firms for both men and women. The smallest size category ranges from 1 to 20 workers. Notably, neither Booth (1991) nor Green and Lemieux (2007) addressed the substance of training courses in their research.

As previously mentioned, Lynch and Black (1998) conducted research on training based on establishment-level data from the U.S. gathered in 1991. The study is unique because of its focus on the substance of training courses offered. They find that even after controlling for an extensive array of worker and firm-level characteristics, large firms are more likely to provide structured training programs than small firms. When the training is 
broken down into substantive areas, larger firms (those with 1000+ employees) are found to be more likely to provide training in computers, teamwork, and basic education. Their results also indicate that firms that adopt high-performance work practices, that are capital intensive, and that hire more educated work forces are more likely to train, regardless of size.

Similarly, Frazis, Gittleman and Joyce (2000) report positive size-training effects. Using a combined individual-establishment level data set, which focused on firms with 50 or more workers operating in the U.S. during 1995, their findings show that 70 percent of firms offered their workers some kind of structured training. They also find a positive correlation between size and incidence of training among employees when the question was whether workers had ever received training from the firm. When the time frame for receiving training is confined to the previous 12 months (as in the present study), however, the size effect did not reach statistical significance. Unlike Lynch and Black (1998), there was no differentiation between types of training firms offered.

Several papers have examined the determinants of training using data from Australia. More recently, Almeida-Santos and Mumford (2004) use the 1995 Australian Workplace Industrial Relations Survey (AWIRS), which combines observations on both the firm and individual levels, to study the incidence of training. To the author's knowledge, it is the only study in the literature to find a negative and statistically significant coefficient on the employer size variable. Similar to other studies relying on data gathered at the firm level, the sampling frame only includes firms with 20 or more employees. In addition, the data do not observe the types of training firms provide. 
Other researchers have used previous installments of the ABS's SET to address the size-training effect. Miller (1994), for example, uses the 1989 SET to assess training differentials between males and females, and, using firm size as a control variable, finds that larger firms were significantly more likely to offer structured training than their smaller counterparts. In addition he finds that, other things equal, male workers are more likely to engage in structured training conducted in-house by the firm. Female workers on the other hand, are more likely to train in programs external to the firm. Wooden (1996) uses the 1993 SET to find that larger firms are substantially more likely to provide structured in-house training than smaller firms. He also documents that the relationship between size and work-related external training is substantially weaker compared to inhouse training, with medium-sized firms being more likely to offer training external to the firm. Both Miller (1994) and Wooden (1996) made use of the "very small" size category established in the SET, and found that workers in very small firms are less likely to train than those in firms employing 100 or more.

Neither of the studies based on SET has focused on the substantive kinds of training offered by firms, and they both used employer size variable with the ' $100+$ Employees' category as the largest, because that was the only option available in the 1989 and 1993 releases of the data. Subsequent to 1993, the 1997, and 2005 installments of the SET observe the employer size variable in the same manner. In fact only the 2001 release, which is used in this study, adds three additional size categories ('100-499', '500999 ', and ' 1000 or more' employees) to the variable.

The literature review suggests that the present research makes two unique contributions to our understanding of size-training effects and provides additional useful 
updates and extensions. First, the study is the first to address the size-training effect, where training is disaggregated by type of training using data at the individual level. Second, the SET allows the researcher to more carefully observe training behavior from the perspective of individuals in very small firms. Furthermore, using the 2001 installment of the SET in particular allows the researcher to conduct a more nuanced analysis of the size-training effect, because it is the only version that observes larger firm sizes. Third, another particularly interesting contribution includes an update of Miller's (1994) comparison of size-training effects by gender.

\section{Discussion of the Data}

The data originate from the 2001 installment of the ABS's SET. The ABS, Australia's official statistical agency, conducted the survey between April and August of 2001. The survey covers private dwelling units, such as houses, flats, and any other structures used as dwelling units, located in urban and rural areas, but it excludes dwellings in sparsely populated areas. The sampling frame also excludes hotels, motels, hostels, short-stay trailer parks, and hospitals. Of 18,000 original dwellings randomly selected into the sample, approximately 13,200 remained after sample loss (e.g. such loss occurs because of abandoned structures, empty flats, or no in-scope residents in a dwelling unit). Trained interviewers attempted to personally interview every resident of a dwelling unit between the ages of 15 and 64 . Of the 13,200 households left after sample 
loss, roughly 12,100 (92 percent) fully responded to the survey. The resulting sample included approximately 24,400 interviews. $^{3}$

Residents responding to the survey were asked questions relating to their job training, other human capital investments, the size of employers, and other variables generally controlled for in labor market analyses. After excluding individuals who were not participating in the labor market, sample sizes of male and female workers are 7,902 and 7,807, respectively. The final samples were further limited to respondents who are currently working for their main period employer, who were not self-employed or working for a self-owned business, who reported knowing the size of their employer, and who were not full time students. Finally, because the questions on training were asked about activities during the previous 12 months, only respondents who reported employment with their firm for one year or more are included in the final sample. This exclusion criterion causes the results to understate the amount of orientation (induction) training, but it ensures that workers who reported training actually received it from the firm in which they are currently employed. After the exclusions, the final samples contain 4,896 males and 4,448 females.

\footnotetext{
${ }^{3}$ The SET surveys are distinct from the monthly Labour Force, Australia survey, which is used to estimate monthly labor market indicators, such as unemployment and participation rates. The $\mathrm{ABS}$, however, whenever possible attempts to use standard question modules so that its data sets are comparable to each other. Differences between the SET and the Labour Force, Australia Survey are detailed in ABS (2003: 65-66). See
} ABS (2003) for a more complete description of the SET. 
This research focuses specifically on structured work-related training. Structured training as defined by the SET consists of courses that were undertaken in Australia, were work-related, had a structured format, and occurred within 12 months prior to the interview. Examples of structured training courses include training seminars, workshops, audio-visual presentations, and conferences devoted to training, as well as class-room style instruction or self-paced training courses. This definition explicitly excludes unstructured training such as learning by doing, asking questions of co-workers, or other ad hoc methods of learning about production processes (ABS 2002: 76).

There are two main types of structured training: 'In-House', defined as training courses primarily attended by those who are working for the respondent's employer or business at the time of the training, and 'External', defined as training courses primarily attended by those not working for the respondent's employer or business at the time of the training. The results in Table 1 show a clear positive correlation between size of the firm and the incidence of completing at least one in-house training course. ${ }^{4}$ The incidence

\footnotetext{
${ }^{4}$ To the extent that training policies and practices are made at the level of the firm, it would seem reasonable to measure firm-size with the number of employees in the entire firm rather than the number of employees in the establishment. There is not a consensus in the literature on which size measure is the better. Some labor market studies using data from Australia have opted to control for the size of the firm (e.g. Wooden 1996; Waddoups 2005), while others have used establishment size (Booth and Katic 2011; Miller and Mulvey 1996). The size measure used in this paper represents the number of employees in all the firm's establishments throughout Australia.
} 
of in-house training in firms with fewer than 10 workers lies between 7.0 and 10.7 percent among males and females, respectively. The training incidence figures for the firms with 1000+ employers are much larger, showing that roughly 62 percent of workers in the sample report in-house training. ${ }^{5}$

Table 1 about here

It is reasonable to expect that larger firms train on an in-house basis more frequently because of economies of scale (Black, Noel, and Wang 1999), or perhaps because they are more likely to produce goods and services using more sophisticated,

${ }^{5}$ Other results not displayed in Table 1 show that 92.8 percent of male respondents and 94.0 percent of female respondents perceive their in-house training courses to be transferable to other firms. For external training, the figures on transferability are 98.1 percent for males and 97.9 percent for females. Thus most of the training does not appear to fit within Becker's (1962) classic description of firm-specific training. In addition, a large majority of workers did not incur costs in either their in-house or external training courses. Only 2.7 percent of males and 6.1 percent of females reported incurring costs in in-house training. The figures for external training were somewhat higher at 8.5 percent for males and 14.3 percent for females. These figures suggest that a vast majority of the training that is the subject of this paper is both transferable and paid for by firms. An extensive literature has developed around explaining conditions under which firms will invest in general or transferable training. See Acemoglu and Pischke (1999) as an example. 
capital intensive production processes, which require more training (Troske 1999). It may also be the case, however, that smaller firms, because of lack of economies of scale, conduct their training externally rather than internally. Results in Table 1 show that there does appear to be some substitution of external for in-house training among smaller firms. Indeed, workers in the largest firms seem to be slightly less likely to train externally than those in the smallest firms.

To compare the incidence of any structured training course, I combined the two categories so that respondents are considered to have trained if they engaged in either inhouse or external training, or both. The results under 'Any Structured Training' in Table 1 clearly demonstrate the large advantage in structured training enjoyed by employees of larger firms. Whereas between one-fifth of male and one-fourth of female workers in the smallest firms reported training in the previous year, two-thirds of workers in the largest firms trained. ${ }^{6}$ Even respondents employed at firms with between 100 and 499 employers are 10-12 percentage points less likely to train than those employed in the largest employers.

The training incidence figures tabulated by firm size in Table 1 demonstrate roughly the same pattern for male and female workers. The average hours of training, conditional on receiving training, however, reveal a potentially significant difference between the two groups. In every cell for both types of training, average hours of

\footnotetext{
${ }^{6}$ Previous research focused on unstructured (informal) on-the-job training does not reveal large differences by firm size, which indicates that smaller firms are not substituting unstructured training for structured training compared to their larger counterparts (Waddoups 2010).
} 
training are larger for males. I will address whether such differences hold up in a multivariate context in a subsequent section of the paper.

Table 2 provides additional details on the characteristics of the sample by employer size and gender. The results indicate that the average age of male workers tends to increase by firm size for men, but not for women. Smaller firms are much more likely to employ less-educated workers (less than year 12) and much less likely to have employees that report a university degree. Similarly, average tenure with an employer grows as employer size increases. Employment tenure averages 5.7 years in very small firms and 10.5 years in large firms among males. The figures on tenure are 5.8 years and 8.4 years among females. As expected, part-time and casual work status are significantly less likely to be reported among respondents in larger firms, but it is interesting to note the much greater likelihood of such work among females regardless of size. Finally, Table 2 shows that union membership and employment in the public sector are much more likely to be associated with larger firm sizes.

Table 2 about here

\section{Empirical Model and Estimation Results}

By estimating a model of the determinants of training while controlling other variables besides employer size, it is possible to get a more complete view of the decision to train. The empirical strategy is to estimate the probability of training $(P)$ using a maximum likelihood probit procedure according to the following model: 


$$
P=\alpha+\beta(\text { Employer Size })+\delta X+\varepsilon,
$$

where $P$ represents the probability of training in the previous 12 months, Employer Size represents a vector of size dummy variables that control for employer size, $X$ is a vector of other variables that may affect the probability of training, $\beta$ and $\delta$ are vectors of parameters to be estimated and $\varepsilon$ is a random error term.

Incidence of Training The first probit model estimates the probability that a worker who has been with the firm for at least one year engaged in one or more in-house training courses during the 12 months prior to the interview. The equation was estimated separately for males and females. The second model estimates the probability of external training, again separately for male and female workers, and the third estimates the probability of either in-house or external training, or both. The parameter estimates in Table 3 are presented as marginal effects with '1000+ employees' as the omitted firm-size category. $^{7}$

The results in Table 3 reinforce the summary statistics in Table 1, exhibiting a clearly decreasing probability of in-house training as the size of the firm increases, even after controlling for other factors that may have affected the incidence of training. As marginal effects, the coefficient on the '<10 Empl' variable has the following definition: everything else equal, a worker in a firm with fewer than 10 employees is 42 percentage points less likely to have engaged in in-house training in the previous 12 months than a

\footnotetext{
${ }^{7}$ Appendix Table 1 provides descriptive summary statistics for variables used in the estimations and Appendix Table 2 provides all coefficients and $\mathrm{z}$ statistics from the equations in Table 3.
} 
worker in a firm with $1000+$ workers. For females the corresponding probability figure is 39 percentage points. Notice also that the coefficients on the '100-499 Empl' and '500999 Empl' are -.055 and -.112. Both the coefficients are negative, as expected, statistically significant, and arguably economically meaningful as well. Such size-training effects would have been unobservable if the practice of setting the largest firm size category at ' $100+$ ', as in the SIPP and other installments of the SET data, would have been employed. There is also a statistically significant difference between the coefficient on the '<10 Empl' variable and the '20-99 Empl' variable, which is equivalent to the smallest firm-size category that would be observed in studies where firm-level data are used (i.e. Green, Machin and Manning 1999; Lynch and Black 1998). These results suggest that having access to data on training behavior of very small firms provides a more complete picture of the size-training relationship. Finally, the findings indicate that while there appear to be differences in point estimates of coefficients between male and female workers, they generally do not reach statistical significance.

Table 3 about here

Compared to the results on in-house training, the results on external training exhibit much less variation by firm size. Notably, all coefficients are positive and all but one is statistically significant at conventional levels. These results suggest that the largest firms are less likely to train workers externally than their smaller counterparts. In contrast to the size/in-house training profiles, the size/external training profiles are relatively flat (especially for males), thus there appears to be no statistically relevant differences in the 
incidence of external training among the size categories representing fewer than 1,000 employees.

The forgoing analysis suggests an interesting question: to what extent do firms in the smaller categories compensate for less in-house training by engaging in more external training? To test this, I estimated the probit model again with the dependent variable taking on the value of 1 if any structured training (either in-house or external) is observed. The results in Table 3 indicate that the general pattern established in panel 1, describing differences in in-house training, holds for the combined training variable in panel 3 , where there is a monotonically decreasing probability of structured training observed as one moves down the employer size spectrum.

To the extent that structured work-related training plays a critical role in forming an economy's human capital stock, there is clearly a lower likelihood that workers will receive structured training in smaller firms. Moreover, although the qualitative pattern of the results is not surprising based on findings of previous research, this research does provide additional insight into the magnitude of the decline in training among very small firms, which is not available in other studies. For example, if the size category stopped at the '20-99 Empl' category, the difference in the probability of training between the '1000+Empl' and '20-99 Empl' categories would be a significant 196 probability points for males and .124 for females. Accounting for the training experiences of workers in the '<10 Empl' category, which, as stated previously, employs 15 percent of workers in Australia, however, leads to another .173 probability point drop for males and .166 point drop for females, figures which are clearly statistically and economically meaningful. Although lower training levels in smaller firms does not necessarily indicate that there is 
less than socially optimal levels of training occurring -- perhaps production technology in the smallest firms is less likely to require training -- it does raise cause for concern, and suggests that additional research on the topic is warranted.

Intensity of Training A weakness of the probit model is that it measures the incidence of training without measuring its intensity, which is defined here as hours of training during the previous year. For example, it may be that while larger firms are more likely to train, smaller firms provide more hours of training, or perhaps that while male and female workers have similar incidences of training, male workers receive substantially more hours. Fortunately, the SET asks respondents to report how many hours during the previous 12 months they engaged in in-house or external training. Recall that Table 1 contained descriptive statistics of training hours for in-house, external, and any structured training variables. For those receiving training, the average amount was 36.8 hours and 25.2 hours for males and females, respectively. The intensity of training grows as firm size increases, and males in the largest firms have significantly higher rates of training than females.

Similar to the analysis of the incidence of training, I estimated the determinants of the hours of training using multivariate analysis, this time with a maximum likelihood tobit procedure. The equations were again estimated separately for males and females and also separately for each training category. The model is given by,

\section{Hours of Training $=\alpha+\beta_{1}$ (Employer Size $)+\delta X+\varepsilon$.}

The results are located in Table 4. 


\section{Table 4 about here}

Similar to the results on the incidence of training, Table 4 indicates that workers in smaller firms train on an in-house basis less intensely than in larger firms. The model predicts that male workers in firms with fewer than 10 workers will train approximately 120 fewer hours than similarly situated workers in firms with fewer than $1000+$ workers. The results in Table 4 indicate 56 fewer training hours in the '20-99 Empl' category relative to ' $1000+$ Empl' category. There is also a statistically significant difference in the coefficients describing male and female training hours, where males train significantly more intensely in all size categories.

Turning now to the results on external training, there appears to be more hours provided among firms with fewer than 1,000 workers relative to the $1000+-$ worker firms. The results, similar to those found in the incidence equations, hold for both men and women, and suggest that, relative to the largest firms, the medium- and small-sized firms substitute external for in-house training. Although the pattern in coefficients appears more pronounced among female workers, the differences by gender do not reach conventional levels of significance.

When considering the 'Hours of Any Structured Training' variable, the pattern of coefficients clearly forms a monotonically decreasing level of training intensity as the firm size becomes smaller. All coefficients are negative and statistically significant, indicating that workers in the largest firms train more than their counterparts in smaller firms. 
Similar to the findings on the incidence equations, if the sample only focused on workers in firms with $20+$ workers, as is the case with establishment level data, the sizetraining effect would look substantially more attenuated. For males the estimate would be only 41 fewer hours of structured training compared to the 77 fewer hours when the smallest firms are included, and for females the estimate would be only 14 hours of training fewer instead of the 33 hours fewer. These results reinforce the importance of accounting for very small firms' training behavior when addressing the size-training effect. Similar to the findings on the incidence equations, the magnitude and statistical significance on the coefficients of the '100-499 Empl' and '500-999 Empl' variables also suggest that not being able to account for larger firms would limit the usefulness of the data for detecting size-training effects.

The coefficients associated with the smallest four size categories also exhibit differences by gender, where males engage in significantly more training hours than females. In terms of the differences in training by firm size, the tobit results are qualitatively similar to the probits for the three training variables. The tobit models, however, reveal that female workers along much of the firm-size spectrum receive significantly fewer hours of training, which did not emerge nearly as strongly in the incidence equations. Differences in training by gender, thus, tend to manifest themselves as fewer hours for females more than a lower likelihood that training will occur. Types of Training The two previous sections addressed the size-training effect with respect to incidence and intensity. The next step is to examine the content of training. It is rare that a study on the determinants of training deals with content simply because it is generally not available in the data. The notable exception, as previously mentioned, is 
Lynch and Black (1998), which addressed content in the size-training effect using company-level data from the U.S.

Table 5 summarizes the types of training courses in which workers participated during the previous 12 months. The sample sizes are not the same as in previous tables because respondents are counted once for each type of training course conducted. Thus if trainees participated in a computing course and a health and safety seminar, they would be counted twice. By far the most commonly reported kind of training falls in the management/professional category, which accounts for between 26 and 38 percent of all courses. The next most common substantive area, roughly 15 percent of courses reported, is in the field of technical/paraprofessional training. Health and Safety courses are also commonly reported, accounting for approximately 12 percent of structured training courses. Other kinds of training are much less commonly observed. For example, Australian firms are not committing much of their resources to training workers in English, literacy and numeracy. This finding is reminiscent of Lynch and Black (1998: 71) that found a relatively low proportion of American firms providing training in basic education. Not surprisingly a pattern of males being more likely to engage in trade and craft skills and females in clerical skills also emerges in Table 5.

Table 5 about here

The previous results suggest that smaller firms are significantly less likely to engage in training overall. A remaining question, and one that has been less-studied in the literature, is whether one can gain a better understanding of the nature of the size-training 
effect by disaggregating training by its type. Thus to the extent that there may be a training deficit related to small firms, the question becomes, what type of training are small firms less likely to provide? Indeed, if there are gaps in training experience based on firm size, having an understanding of how big the deficits are and where they lie would seem to be important information for interested analysts and policymakers.

To obtain a better understanding of such training patterns, equation 1 is estimated again, but this time $P$ represents the probability of training in a given substantive area. Like the methodology that produced results in Table 3, I estimated separate equations for in-house, external, and any structured training by gender to arrive at the results listed in Table 6. Note that not all the training categories from Table 5 are represented in Table 6, because some training categories are rare enough that the resulting estimates were unreliable.

Table 6 about here

In general, the results in Table 6 exhibit the same general pattern of smaller probabilities of 'in-house' and 'any structured training' as was revealed in Table 3. At this level of disaggregation there are, however, very few differences in probability of training between male and female workers.

Focusing first on in-house management and professional training, the results show a clear and monotonically decreasing training probability as firm size decreases. Based on respondents' experience, the model predicts that all else equal, workers in the smallest firms are approximately 10 percentage points less likely to train than their 
counterparts in the largest firms. In addition, the difference between the coefficients on the '<10 Empl' and '20 - 99 Empl' variables for both males and females is statistically significant ( $\mathrm{p}$-value $<0.10$ ), which suggests that not observing the smallest firms tends to mask real behavioral differences based on firm size. Moreover, statistically significant differences in the coefficients of the largest firms and firms in the ' 100 - 499 Empl' category suggest that being able to observe firm sizes of $1000+$ is also an important for our understanding of the size-training relationship.

Similar to the results in Table 3, the coefficients on external training are positive and generally statistically significant for firms employing fewer than 500 employees. Again, such results suggest that being able to observe larger firm sizes (1000+ employees) adds to our understanding of the training process. Significant differences in training incidence of the smallest firms and their slightly larger counterparts, however, do not register for external training. Turning to the any structured training category, the results for males appear qualitative similar to those in the 'in-house' group. That is, the pattern exhibits a progressively decreasing incidence of training with smaller firm sizes. The results for females are less clear, suggesting that firm size is not as important a determinant of management and professional training taken as a whole for female workers.

Other results in Table 6 exhibit similar patterns. For example, consider the 'Technical and Paraprofessional' category, where the coefficients on the '< 10 Empl' variable in the in-house equations are significantly smaller than coefficients on the ' 20 99 Empl' variables, which suggests that observing the smallest firm sizes is important to our understanding of overall technical and paraprofessional training. Similarly, the 
statistically significant estimates in the female 'in-house' equation on the larger two size categories indicates that larger firms are more likely to train, and suggests that not being able to differentiate between firms in the larger size categories would detract from our understanding of the training process.

Moving to the combined training category in the male equation, the coefficient on the smallest size category is significantly smaller than the coefficient in the '20-99 Empl' category, and among females, the coefficients on the 'larger two size categories are statistically significant. This pattern reinforces the notion that being able to observe the largest and smallest firms increases our understanding of the size-training effect also when training events are disaggregated by type.

Safety training is another relatively common substantive field for training as is evident from Table 5. The results in Table 6 suggest that although there does not appear to be much difference in the incidence of training in the three largest size categories, a real difference emerges upon comparing the smallest firms with the others. Not only is there a large difference between the smallest and largest firms, but there is also a statistically significant and economically meaningful difference between the firms with fewer than 10 workers and those in the '20-99 Empl' category.

\section{Conclusion}

The purpose of this study is to examine further the relationship between firm size and structured work-related training. Relying on a rich data source on training experience in the Australian economy, the research provides additional insight into the size-training question. Perhaps the most novel contribution of this research is its treatment of the size- 
training effect based on substantive kinds of training. The results reveal that the most common types of training, management/professional, health/safety, and technical/paraprofessional, follow the same pattern as more aggregated training measures, which is a declining incidence of training as one moves from larger to smaller firms. One illuminating finding in this regard is the significant lack of health and safety training that occurs among workers in very small firms. Whether this is a result of less dangerous production technology being used in smaller firms, or whether there is actually a suboptimal level of health and safety training among such firms would be a fruitful topic for future investigation.

The research also suggests that the methodology in much of the literature, in which very small firms are not included in sample frames, produces research that will almost surely fail to capture a significant portion of the potential deficit in work-related training. Firms with fewer than 10 workers, while employing about 15 percent of workers of the Australian economy and 16 percent in the U.S. economy, are much less likely to provide training. To be sure, it is not entirely clear how much of the training deficiency in small firms should be considered economically suboptimal because of the differing nature of production processes across the size spectrum. At the very least, however, the findings suggest that additional research on the adequacy of training practices of very small firms should be considered in future research.

A similar argument about lack of appropriate data applies to the upper end of the firm size distribution. In individual-level data sets lower class limits of firm-size categories are set too low, as in other installments of the SET and the SIPP, where the largest size category is $100+$. The findings here show that important differences in 
training practices occur among firms within a 100+ category that could easily be elucidated with more precisely defined size classes at the upper end of the distribution.

Finally, the study illustrates a serious gap in current U.S. labor market data. The SET provides Australian analysts and policymakers with rich, consistent, and timely data on training practices and educational attainment, which are useful for informing training and education policy. No such data is available in the U.S. Arguably, however, investing resources to gather such data could pay dividends in the form of better informed education and training policy in the future. 


\section{References}

Acemoglu D, Pischke JS (1999) Beyond Becker: training in imperfect labour markets. Economic Journal 109 (453): F112-F142.

Almeida-Santos F, Mumford KA (2004) Employee training in Australia: evidence from AWIRS. The Economic Record 80: S53-S64.

Australian Bureau of Statistics (ABS) (2002) Education and Training Experience, Australia Explanatory Notes, Catalogue 6278.0. Canberra.

Becker G (1962) Investment in human capital: A theoretical analysis. Journal of Political Economy 70 Part 2: 9-49.

Black D, Noel BJ, Wang Z (1999) On-the-job training, establishment size, and firm size: evidence for economies of scale in the production of human capital. Southern Economic Journal 66:82-100.

Booth A (1991) Job related formal training: who receives it and what is it worth?” Oxford Bulletin of Economics and Statistics 53: 281-294.

Booth AL and Katic P (2011) Men at work in a land down-under: testing some predictions of human capital theory. British Journal of Industrial Relations 49: 124.

Brown C, Medoff J (1989) The employer size-wage effect. Journal of Political Economy 97: 1027-1059.

Butani, SJ, Clayton RL, Kapani V, Spletzer JR, Talan, DM, Werking SW (2006) Business employment dynamics: tabulations by employer size. Monthly Labor Review 129: 3-22, February. 
Frazis H, Gittlemman M, Joyce M (2000) Correlates of training: an analysis using both employer and employee characteristics. Industrial \& Labor Relations Review 53: 443-62.

Green DA, Lemieux T (2007) The impact of unionization on the incidence of and sources of payment for training in Canada. Empirical Economics 32: 465-89.

Green F, Machin S and Wilkinson D (1999) Trade unions and training practices in British workplaces. Industrial \& Labor Relations Review 52: 179-95.

Lynch L, Black SE (1998) Beyond the incidence of employer-provided training. Industrial \& Labor Relations Review 52: 64-81.

Miller PW, Mulvey C (1996) Unions, Firm Size and Wages. Economic Record 72: 13853

Miller PW (1994) Gender discrimination in training: an Australian perspective. British Journal of Industrial Relations 32: 539-64.

Oi WY, Idson TL (1999) Firm size and wages" in Ashenfelter O and Card D (eds.) Handbook of Labor Economics, Volume 5. New York: Elsevier Science, North Holland: 2165-2214.

Osterman P (1995) Skill, training and work organizations in American establishments. Industrial Relations 34: 125-45

Troske KR (1991) Evidence on the employer size-wage premium. Review of Economics and Statistics 81: 15-26.

Waddoups CJ (2005) Trade Union Decline and Union Wage Effects in Australia. Industrial Relations 44: 607-24 
Waddoups CJ (2010) Firm size and employer-sponsored training in Australia: new evidence on incidence and intensity. Proceedings of the 62 Annual Meeting of the Labor and Employment Relations Association. Labor and Employment Relations Association, Champaign/Urbana, IL.

Wooden M (1996) Firm size and the provision of employee training: an analysis of the 1993 Survey of Training and Education. Australian and New Zealand Journal of Vocational Education Research 4: 89-120. 
Table 1 Characteristics of Work-Related Training during the Previous 12 Months by Firm Size and Sex

\begin{tabular}{|l|c|c|c|c|c|c|c|}
\hline & \multicolumn{7}{|c}{ Firm Size (Male) } \\
\cline { 2 - 8 } & $<10$ & $10-19$ & $20-99$ & $100-499$ & $500-999$ & $1000+$ & All \\
\hline Proportion Training & & & & & & & \\
\hline In-House Training & 0.070 & 0.161 & 0.286 & 0.441 & 0.511 & 0.615 & 0.415 \\
\hline External Training & 0.138 & 0.161 & 0.177 & 0.202 & 0.200 & 0.144 & 0.161 \\
\hline Any Formal Training & 0.195 & 0.287 & 0.408 & 0.560 & 0.596 & 0.679 & 0.511 \\
\hline Number & 732 & 356 & 724 & 715 & 333 & 2036 & 4896 \\
\hline Conditional on Training & & & & & & & \\
\hline In-House Training (hrs.) & 17.0 & 17.0 & 20.0 & 26.0 & 30.3 & 45.1 & 36.9 \\
\hline External Training (hrs.) & 36.7 & 34.0 & 28.9 & 31.0 & 32.6 & 33.2 & 32.6 \\
\hline Any Formal Training (hrs.) & 32.2 & 28.7 & 26.6 & 31.6 & 36.9 & 47.9 & 40.3 \\
\hline & & & Firm Size (Female) & & \\
\hline & $<10$ & $10-19$ & $20-99$ & $100-499$ & $500-999$ & $1000+$ & All \\
\hline & & & & & & & \\
\hline Proportion Training & 0.107 & 0.238 & 0.335 & 0.472 & 0.531 & 0.627 & 0.446 \\
\hline In-House Training & 0.158 & 0.194 & 0.186 & 0.218 & 0.159 & 0.126 & 0.159 \\
\hline External Training & 0.237 & 0.384 & 0.452 & 0.554 & 0.592 & 0.665 & 0.526 \\
\hline Any Formal Training & 637 & 387 & 720 & 534 & 258 & 1912 & 4448 \\
\hline Number & & & & & & & \\
\hline Conditional on Training & 14.7 & 16.6 & 18.5 & 20.1 & 24.0 & 27.8 & 24.5 \\
\hline In-House Training (hrs.) & 19.8 & 20.9 & 24.4 & 29.3 & 19.1 & 30.1 & 25.8 \\
\hline External Training (hrs.) & 19.9 & 20.9 & 23.8 & 28.6 & 26.6 & 32.0 & 28.6 \\
\hline Any Formal Training (hrs.) & 19.9 & \\
\hline
\end{tabular}

Source: Survey of Education and Training, 2001, Australian Bureau of Statistics. Excluded are respondents with no earnings, the self employed, students, and those who have been with their employers for less than one year. 
Table 2 Summary Statistics of Workers in Sample by Firm Size and Sex

\begin{tabular}{|c|c|c|c|c|c|c|}
\hline & \multicolumn{6}{|c|}{ Firm Size (Male) } \\
\hline & $<10$ & $10-19$ & $20-99$ & $100-499$ & $500-999$ & $1000+$ \\
\hline Age & 35.0 & 37.4 & 38.5 & 40.1 & 40.3 & 39.2 \\
\hline Less than Year 12 & 0.359 & 0.332 & 0.287 & 0.279 & 0.249 & 0.232 \\
\hline Year 12 & 0.191 & 0.191 & 0.152 & 0.170 & 0.125 & 0.196 \\
\hline Post Year 12 Training & 0.295 & 0.285 & 0.273 & 0.242 & 0.205 & 0.208 \\
\hline University Degree & 0.155 & 0.192 & 0.287 & 0.308 & 0.421 & 0.364 \\
\hline Tenure with Employer (yrs.) & 5.7 & 6.3 & 7.1 & 8.6 & 9.7 & 10.5 \\
\hline Tenure in Occupation (yrs.) & 9.0 & 10.1 & 10.0 & 10.4 & 10.4 & 10.0 \\
\hline Part Time & 0.168 & 0.094 & 0.096 & 0.072 & 0.046 & 0.087 \\
\hline Casual & 0.308 & 0.167 & 0.106 & 0.076 & 0.073 & 0.060 \\
\hline Union Member & 0.091 & 0.171 & 0.221 & 0.343 & 0.360 & 0.482 \\
\hline Public Sector & 0.009 & 0.023 & 0.097 & 0.184 & 0.254 & 0.383 \\
\hline \multirow[t]{3}{*}{ Sample Size } & 732 & 356 & 724 & 715 & 333 & 2036 \\
\hline & \multicolumn{6}{|c|}{ Firm Size (Female) } \\
\hline & $<10$ & $10-19$ & $20-99$ & $100-499$ & $500-999$ & $1000_{+}$ \\
\hline Age & 38.4 & 37.8 & 39.6 & 39.6 & 38.6 & 38.6 \\
\hline Less than Year 12 & 0.435 & 0.358 & 0.366 & 0.302 & 0.280 & 0.309 \\
\hline Year 12 & 0.216 & 0.213 & 0.185 & 0.202 & 0.198 & 0.193 \\
\hline Post Year 12 Training & 0.128 & 0.130 & 0.123 & 0.073 & 0.107 & 0.084 \\
\hline University Degree & 0.222 & 0.300 & 0.326 & 0.423 & 0.414 & 0.414 \\
\hline Tenure with Employer (yrs.) & 5.8 & 5.6 & 6.5 & 7.3 & 6.8 & 8.4 \\
\hline Tenure in Occupation (yrs.) & 8.9 & 7.9 & 9.6 & 9.4 & 8.7 & 9.0 \\
\hline Part Time & 0.594 & 0.456 & 0.436 & 0.364 & 0.369 & 0.382 \\
\hline Casual & 0.471 & 0.329 & 0.234 & 0.183 & 0.160 & 0.131 \\
\hline Union Member & 0.043 & 0.100 & 0.236 & 0.291 & 0.270 & 0.449 \\
\hline Public Sector & 0.046 & 0.099 & 0.186 & 0.285 & 0.303 & 0.448 \\
\hline Sample Size & 637 & 387 & 720 & 534 & 258 & 1912 \\
\hline
\end{tabular}


Table 3 The Impact of Firm Size on the Probability of Structured Training in the last 12 Months (Marginal Effects): Absolute Value of Asymptotic $z$ Statistic in Parentheses

\begin{tabular}{|c|c|c|c|c|c|c|c|}
\hline & \multicolumn{2}{|c|}{ In-House Training ${ }^{1}$} & \multicolumn{2}{|c|}{ External Training } & \multicolumn{3}{|c|}{ Any Structured Training } \\
\hline & Male & Female & Male & Female & Male & Fel & male \\
\hline & Coeff. z stat. & Coeff. $\mathrm{z}$ stat. & Coeff. z stat. & Coeff. z stat & Coeff. z stat. & Coeff. & z stat. \\
\hline$<10 \mathrm{Empl}^{2,3}$ & $-0.417(17.47)$ & $-0.394(15.33)$ & $0.057(2.80)$ & $0.153(6.80)$ & $-0.369(14.26)$ & * -0.290 & $0(10.46)$ \\
\hline 10-19 Empl & $-0.313(11.33)$ & $-0.285(10.09)$ & 0.065 (2.65) & $0.154(6.19)$ & $-0.289(9.24)$ & * -0.171 & $1(5.60)$ \\
\hline 20-99 Empl & $-0.231(10.75)^{!}$ & $-0.200(8.56)^{!}$ & 0.059 (3.29) & $0.115(6.23)$ & $-0.196(8.25)^{!}$ & -0.124 & $4(4.94)^{!}$ \\
\hline 100-499 Empl & $-0.119(5.51)$ & $-0.102(3.95)$ & $0.072(4.21)$ & $0.098(5.13)$ & $-0.068(2.87)$ & -0.071 & $1(2.58)$ \\
\hline 500-999 Empl & $-0.077(2.69)$ & $-0.055(1.60)$ & $0.061(2.71)$ & $0.022(0.90)$ & $-0.063(2.03)$ & -0.052 & $2(1.42)$ \\
\hline
\end{tabular}

Source: The data used to generate the estimates were obtained from the Survey of Education and Training, 2001 gathered by the Australian Bureau of Statistics. Excluded are respondents with no earnings, the self employed, those who did not know their employer size, students, and those who have been with their employers for less than one year.

*Statistically significant difference between males and females.

'Statistically significant difference between coefficient on '<10 Empl' and '20-99 Empl' variables.

${ }^{1}$ Independent variables are defined as the probability that a worker reported at least one internal training course, external training course, or any structured training in the last 12 months.

2 The variable for employer size is the number of employees in all the employers' establishments throughout Australia.

${ }^{3}$ The probit equations controls for age, tenure with employer, and tenure in occupation and their squares. It also controls for education, casual employment, public sector employment, marital status, part-time, english speaking ability, region of residence, occupation, and industry of employment. The excluded category is 1000 or more employees. Results of full regression equations are available upon request. 
Table 4 The Impact of Firm Size on the Hours of Training in the last 12 Months (Tobit Models): Absolute Value of Asymptotic z Statistic in Parentheses

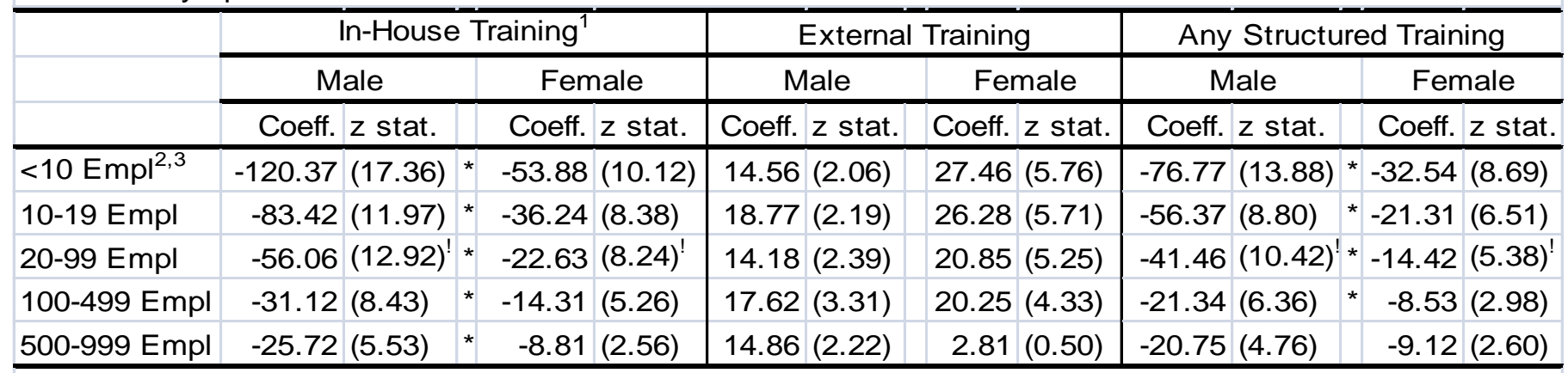

Source: The data used to generate the estimates were obtained from the Survey of Education and Training, 2001 gathered by the Australian Bureau of Statistics. Excluded are respondents with no earnings, the self employed, those who did not know their employer size, students, and those who have been with their employers for less than one year.

*Statistically significant difference between males and females.

'Statistically significant difference between coefficient on '<10 Empl' and '20-99 Empl' variables.

${ }^{1}$ Independent variables are defined as the total hours spent training in an in-house, external or, any structured training courses in the last 12 months.

${ }^{2}$ The variable for employer size is the number of employees in all the employers' establishments throughout Australia.

${ }^{3}$ The tobit equation controls for age, tenure with employer, and tenure in occupation and their squares. It also controls for education, casual employment, public sector employment, marital status, part-time, english speaking ability, region of residence, occupation, and industry of employment. The excluded category is 1000 or more employees. Results of full regression equations are available upon request. 
Table 5 Type of Training Courses (in percent)

\begin{tabular}{|l|c|c|c|c|}
\hline & In-House & External & In-House & External \\
\hline Clerical & 0.9 & 1.4 & 4.9 & 5.9 \\
\hline Computing & 7.1 & 9.9 & 8.6 & 12.6 \\
\hline English, Literacy, Numeracy & 0.3 & 0.1 & 1.1 & 1.8 \\
\hline Health and Safety & 14.3 & 12.6 & 14.8 & 10.2 \\
\hline Induction & 2.7 & 2.3 & 2.6 & 1.3 \\
\hline Labouring & 1.7 & 0.6 & 0.9 & 0.6 \\
\hline Management/Professional & 26.2 & 30.4 & 28.7 & 37.9 \\
\hline Music & 0.1 & 0.1 & 0.5 & 0.4 \\
\hline Sales, Personal Service & 8.5 & 4.7 & 13.1 & 7.2 \\
\hline Supervision & 4.3 & 2.4 & 3.9 & 2.1 \\
\hline Trade and Craft & 9.6 & 12.4 & 3.8 & 5.2 \\
\hline Technical, Para-Professional & 15.9 & 16.7 & 16.2 & 14.4 \\
\hline Transport, Machinery Operation & 8.4 & 6.4 & 1.0 & 0.4 \\
\hline & & & & \\
\hline Number & & & & \\
\hline
\end{tabular}

Source: Survey of Education and Training, 2001, Australian Bureau of Statistics. Excluded are respondents with no earnings, the self employed, students, and those who have been with their employers for less than one year.

${ }^{1}$ Refers to number of training spells, not to the number of individuals in the sample. 
Table 6 The Impact of Firm Size on the Probability of Various Types of Training in the last 12 Months (Marginal Effects): Absolute Value of Asymptotic z Statistic in Parentheses

\begin{tabular}{|c|c|c|c|c|c|c|c|c|c|c|c|c|c|}
\hline & \multicolumn{5}{|c|}{ In-House Training ${ }^{1}$} & \multicolumn{4}{|c|}{ External Training } & \multicolumn{4}{|c|}{ Any Structured Training } \\
\hline & \multicolumn{3}{|c|}{ Male } & \multicolumn{2}{|c|}{ Female } & \multicolumn{2}{|c|}{ Male } & \multicolumn{2}{|c|}{ Female } & \multicolumn{2}{|c|}{ Male } & \multicolumn{2}{|c|}{ Female } \\
\hline & Coeff. & z stat. & & Coeff. & $z$ stat. & Coeff. & z stat. & Coeff. & z stat. & Coeff. & $z$ stat. & Coeff. & z stat \\
\hline \multicolumn{14}{|l|}{ Computing } \\
\hline$<10 \mathrm{Empl}^{2,3}$ & -0.038 & $(4.88)$ & * & -0.058 & $(4.55)$ & 0.003 & $(0.45)$ & 0.033 & (3.68) & -0.039 & (3.55) & -0.022 & (1.65) \\
\hline 10-19 Empl & -0.032 & (3.96) & & -0.041 & (3.00) & 0.003 & $(0.37)$ & 0.010 & $(1.05)$ & -0.037 & (3.16) & -0.029 & (1.96) \\
\hline 20-99 Empl & -0.017 & $(2.91)^{!}$ & * & -0.042 & (4.05) & 0.007 & $(1.20)$ & 0.018 & $(2.47)$ & -0.018 & (1.99) & -0.026 & (2.23) \\
\hline 100-499 Empl & -0.010 & $(1.76)$ & & -0.011 & $(0.97)$ & 0.004 & $(0.77)$ & 0.028 & (3.44) & -0.009 & $(1.00)$ & 0.011 & $(0.85)$ \\
\hline 500-999 Empl & 0.002 & $(0.29)$ & & 0.011 & $(0.70)$ & 0.010 & $(1.44)$ & -0.006 & $(0.70)$ & 0.012 & $(1.00)$ & 0.003 & $(0.16)$ \\
\hline Predicted Prob & 0.031 & & & 0.067 & & 0.016 & & 0.022 & & 0.055 & & 0.079 & \\
\hline \multicolumn{14}{|l|}{ Health/Safety } \\
\hline$<10 \mathrm{Empl}$ & -0.117 & (9.24) & & -0.108 & (7.84) & -0.001 & $(0.17)$ & 0.015 & (1.79) & -0.129 & (9.08) & -0.104 & (6.50) \\
\hline 10-19 Empl & -0.082 & $(6.14)$ & & -0.077 & (5.58) & -0.002 & $(0.20)$ & 0.024 & $(2.38)$ & -0.104 & $(6.26)$ & -0.065 & (3.69) \\
\hline 20-99 Empl & -0.071 & $(6.63)^{!}$ & & -0.043 & $(3.71)^{!}$ & 0.006 & $(0.78)$ & 0.023 & (3.30) & -0.079 & $(6.00)^{!}$ & -0.035 & $(2.50)$ \\
\hline 100-499 Empl & -0.029 & (2.68) & & -0.014 & (1.05) & 0.025 & $(3.16)$ & 0.007 & (1.01) & -0.018 & (1.32) & -0.010 & $(0.61)$ \\
\hline 500-999 Empl & -0.026 & $(1.82)$ & & 0.011 & (0.63) & 0.006 & $(0.59)$ & 0.026 & $(2.36)$ & -0.032 & $(1.87)$ & 0.020 & $(0.98)$ \\
\hline Predicted Prob & 0.125 & & & 0.092 & & 0.027 & & 0.021 & & 0.125 & & 0.122 & \\
\hline \multicolumn{14}{|l|}{ Mgt/Prof. } \\
\hline$<10 \mathrm{Empl}$ & -0.105 & $(7.81)$ & & -0.098 & (6.67) & 0.028 & $(2.40)$ & 0.089 & $(5.85)$ & -0.092 & $(5.54)$ & -0.042 & (2.06) \\
\hline 10-19 Empl & -0.072 & $(5.04)$ & & -0.062 & (4.34) & 0.026 & $(1.92)$ & 0.104 & (6.01) & -0.070 & (3.59) & 0.002 & $(0.07)$ \\
\hline 20-99 Empl & -0.064 & $(6.15)^{!}$ & & -0.053 & $(4.73)^{!}$ & 0.022 & $(2.37)$ & 0.052 & $(4.50)$ & -0.064 & $(4.42)$ & -0.023 & (1.35) \\
\hline 100-499 Empl & -0.031 & $(2.97)$ & & -0.036 & (3.13) & 0.019 & $(2.25)$ & 0.057 & $(4.85)$ & -0.027 & $(1.90)$ & -0.015 & $(0.88)$ \\
\hline 500-999 Empl & -0.022 & $(1.71)$ & & 0.000 & $(0.01)$ & 0.002 & $(0.18)$ & 0.004 & $(0.29)$ & -0.039 & (2.18) & -0.005 & $(0.22)$ \\
\hline Predicted Prob & 0.084 & & & 0.089 & & 0.040 & & 0.044 & & 0.134 & & 0.150 & \\
\hline \multicolumn{14}{|l|}{ Trade/Craft } \\
\hline$<10 \mathrm{Empl}$ & -0.032 & $(5.44)$ & * & -0.006 & (2.07) & 0.012 & $(2.20)$ & 0.008 & (2.08) & -0.027 & (3.22) & 0.001 & $(0.09)$ \\
\hline 10-19 Empl & -0.023 & (3.22) & * & -0.006 & (1.55) & 0.011 & $(1.60)$ & 0.010 & (2.15) & -0.021 & (1.95) & 0.001 & $(0.14)$ \\
\hline 20-99 Empl & -0.011 & $(1.85)^{!}$ & & 0.003 & (0.91) & 0.013 & $(2.34)$ & 0.004 & (1.24) & -0.001 & $(0.14)$ & 0.003 & $(0.57)$ \\
\hline 100-499 Empl & -0.009 & $(1.48)$ & & 0.005 & (1.23) & 0.010 & $(1.74)$ & 0.012 & (2.62) & -0.007 & $(0.81)$ & 0.019 & (2.41) \\
\hline 500-999 Empl & -0.008 & $(1.00)$ & & 0.003 & $(0.67)$ & 0.004 & $(0.55)$ & 0.000 & $(0.02)$ & -0.005 & $(0.41)$ & 0.006 & $(0.67)$ \\
\hline Predicted Prob & 0.028 & & & 0.008 & & 0.012 & & 0.005 & & 0.047 & & 0.019 & \\
\hline
\end{tabular}


Table 6 cont. The Impact of Firm Size on the Probability of Various Types of Training in the last 12 Months (Marginal Effects): Absolute Value of Asymptotic z Statistic in Parentheses

\begin{tabular}{|c|c|c|c|c|c|c|c|c|c|c|c|c|}
\hline & \multicolumn{4}{|c|}{ In-House Training $^{1}$} & \multicolumn{4}{|c|}{ External Training } & \multicolumn{4}{|c|}{ Any Structured Training } \\
\hline & \multicolumn{2}{|c|}{ Male } & \multicolumn{2}{|c|}{ Female } & \multicolumn{2}{|c|}{ Male } & \multicolumn{2}{|c|}{ Female } & \multicolumn{2}{|c|}{ Male } & \multicolumn{2}{|c|}{ Female } \\
\hline & Coeff. & z stat. & Coeff. & z stat. & Coeff. & z stat. & Coeff. & z stat. & Coeff. & z stat. & Coeff. & z stat \\
\hline \multicolumn{13}{|l|}{ Tech/Para-Prof. } \\
\hline$<10 \mathrm{Empl}$ & -0.050 & $(5.45)$ & -0.042 & $(5.16)$ & -0.002 & $(0.32)$ & 0.028 & (3.48) & -0.060 & $(5.00)$ & -0.033 & (3.02) \\
\hline 10-19 Empl & -0.039 & $(4.29)$ & -0.029 & (3.47) & -0.005 & $(0.55)$ & 0.015 & (1.91) & -0.051 & (3.86) & -0.024 & $(1.96)$ \\
\hline 20-99 Empl & -0.028 & $(4.18)^{!}$ & -0.020 & (3.25) & 0.002 & $(0.31)$ & 0.017 & (2.79) & -0.034 & (3.37) & -0.014 & $(1.53)$ \\
\hline 100-499 Empl & -0.011 & $(1.70)$ & -0.020 & (3.23) & 0.010 & $(1.65)$ & 0.000 & $(0.05)$ & -0.005 & $(0.53)$ & -0.024 & $(2.60)$ \\
\hline 500-999 Empl & -0.006 & $(0.73)$ & -0.022 & $(2.82)$ & 0.003 & $(0.43)$ & 0.002 & $(0.29)$ & -0.002 & $(0.17)$ & -0.024 & $(2.05)$ \\
\hline Predicted Prob & 0.038 & & 0.035 & & 0.023 & & 0.014 & & 0.068 & & 0.055 & \\
\hline
\end{tabular}

Source: The data used to generate the estimates were obtained from the Survey of Education and Training, 2001 gathered by the Australian Bureau of Statistics. Excluded are respondents with no earnings, the self employed, those who did not know their employer size, students, and those who have been with their employers for less than one year.

*Statistically significant difference between males and females.

'Statistically significant difference between coefficient on '<10 Empl' and '20-99 Empl' variables.

${ }^{1}$ Independent variables are defined as the probability that a worker reported at least one internal training course, external training course, or any structured training course of the type listed in the previous 12 months.

${ }^{2}$ The control for employer size is the number of employees in all the employers' establishments throughout Australia.

${ }^{3}$ The probit equations controls for age, tenure with employer, and tenure in occupation and their squares. It also controls for education, casual employment, public sector employment, marital status, part-time, english speaking ability, region of residence, occupation, and industry of employment. Results of full regression equations are available upon request. 
Appendix Table 1 Summary Statistics of Variables Used in the Analysis

\begin{tabular}{|c|c|c|c|c|}
\hline \multirow[b]{2}{*}{ Variables } & \multicolumn{2}{|c|}{ Male } & \multicolumn{2}{|c|}{ Female } \\
\hline & Mean & Std. Dev. & Mean & Std. Dev \\
\hline In-House Training & 0.415 & --- & 0.446 & --- \\
\hline External Training & 0.161 & --- & 0.159 & --- \\
\hline Any Formal Training & 0.511 & --- & 0.526 & --- \\
\hline Age & 38.496 & 11.7 & 38.797 & 11.6 \\
\hline Duration with Employer & 8.602 & 7.4 & 7.242 & 6.2 \\
\hline Duration in Occupation & 9.930 & 8.3 & 9.020 & 7.8 \\
\hline Education: Postgrad & 0.039 & --- & 0.030 & --- \\
\hline Education: Grad. Diploma & 0.045 & --- & 0.064 & --- \\
\hline Education Bach. Degee & 0.125 & -- & 0.161 & --- \\
\hline Education Adv. Diploma & 0.092 & --- & 0.107 & --- \\
\hline Education: Cert. III or IV & 0.231 & --- & 0.088 & --- \\
\hline Education: Cert. I or II & 0.008 & --- & 0.011 & --- \\
\hline Education: Other Cert. & 0.002 & --- & 0.002 & --- \\
\hline Education: Year 12 & 0.180 & --- & 0.198 & --- \\
\hline Education: Year 11 & 0.064 & --- & 0.078 & --- \\
\hline Education: Year 10 & 0.127 & --- & 0.196 & --- \\
\hline Education: Year 9 & 0.038 & --- & 0.032 & --- \\
\hline Education : Year 8 or less & 0.036 & --- & 0.023 & --- \\
\hline Firm Size: less than 10 & 0.158 & --- & 0.148 & --- \\
\hline Firm Size: $10-19$ & 0.074 & --- & 0.086 & --- \\
\hline Firm Size: 20 - 99 & 0.150 & --- & 0.162 & --- \\
\hline Firm Size: 100 - 499 & 0.143 & --- & 0.116 & --- \\
\hline Firm Size: 500 - 999 & 0.062 & --- & 0.057 & --- \\
\hline Firm Size: More than 1000 & 0.414 & -- & 0.431 & --- \\
\hline Casual Employment & 0.117 & --- & 0.223 & --- \\
\hline Union Member & 0.331 & --- & 0.296 & --- \\
\hline Public Sector Employment & 0.218 & -- & 0.289 & --- \\
\hline Part-Time Employment & 0.097 & --- & 0.426 & --- \\
\hline Married & 0.665 & --- & 0.653 & --- \\
\hline Disabled & 0.219 & -- & 0.194 & --- \\
\hline Born Eng. Speaking Ctry. & 0.115 & --- & 0.099 & -- \\
\hline Born in Non-Eng. Speaking & 0.138 & --- & 0.126 & --- \\
\hline Region New South Wales & 0.337 & --- & 0.335 & --- \\
\hline Region: Victoria & 0.252 & --- & 0.258 & --- \\
\hline
\end{tabular}




\begin{tabular}{|c|c|c|c|c|}
\hline \multirow[t]{2}{*}{ Appendix Table 1 (cont.) } & & & & \\
\hline & \multicolumn{2}{|c|}{ Male } & \multicolumn{2}{|c|}{ Female } \\
\hline Variables & Mean & Std. Dev. & Mean & Std. Dev. \\
\hline Region: Queensland & 0.179 & --- & 0.179 & --- \\
\hline Region: South Australia & 0.078 & --- & 0.074 & --- \\
\hline Region: Western Australia & 0.101 & --- & 0.102 & --- \\
\hline Region: Other & 0.054 & --- & 0.053 & --- \\
\hline Occupation: Manager & 0.090 & --- & 0.030 & --- \\
\hline Occupation: Professional & 0.187 & --- & 0.261 & --- \\
\hline Occupation: Para-Prof. & 0.141 & --- & 0.099 & --- \\
\hline Occupation: Trade & 0.201 & --- & 0.026 & --- \\
\hline Occupation Adv. Clerical & 0.011 & --- & 0.071 & --- \\
\hline Occupation: Inter. Clerical & 0.095 & --- & 0.288 & --- \\
\hline Ocupation: Prod./Transp. & 0.138 & --- & 0.026 & --- \\
\hline Occupation Elem. Clerical & 0.060 & --- & 0.133 & --- \\
\hline Occupation: Labourer & 0.079 & --- & 0.065 & --- \\
\hline Industry: Agriculture & 0.025 & --- & 0.007 & --- \\
\hline Industry: Mining & 0.019 & --- & 0.004 & --- \\
\hline Industry: Manufacturing & 0.200 & --- & 0.070 & --- \\
\hline Industry: Utilities & 0.014 & --- & 0.002 & --- \\
\hline Industry: Construction & 0.076 & --- & 0.010 & --- \\
\hline Industry: Accomodation & 0.036 & --- & 0.054 & --- \\
\hline Industry: Wholesale Trade & 0.060 & --- & 0.030 & --- \\
\hline Industry: Retail Trade & 0.109 & --- & 0.157 & --- \\
\hline Industry: Transportation & 0.067 & --- & 0.027 & --- \\
\hline Industry: Communication & 0.031 & --- & 0.015 & --- \\
\hline Industry: Finance & 0.040 & --- & 0.058 & --- \\
\hline Industry: Property & 0.092 & --- & 0.099 & --- \\
\hline Industry: Government & 0.072 & --- & 0.058 & --- \\
\hline Industry: Education & 0.059 & --- & 0.152 & --- \\
\hline Industry: Health & 0.038 & --- & 0.194 & --- \\
\hline Industry: Culture & 0.022 & --- & 0.023 & --- \\
\hline Industry: Personal Serv. & 0.040 & --- & 0.039 & --- \\
\hline Number of Observations & 4,896 & & 4,497 & \\
\hline
\end{tabular}

Source: Survey of Education and Training, 2001, Australian Bureau of Statistics. Excluded are respondents with no earnings, the self employed, students, and those who have been with their employers for less than one year. 
Appendix Table 2 The Impact of Firm Size on the Probability of Structured Training in the last 12 Months (Marginal Effects): Absolute Value of Asymptotic z Statistic in Parentheses

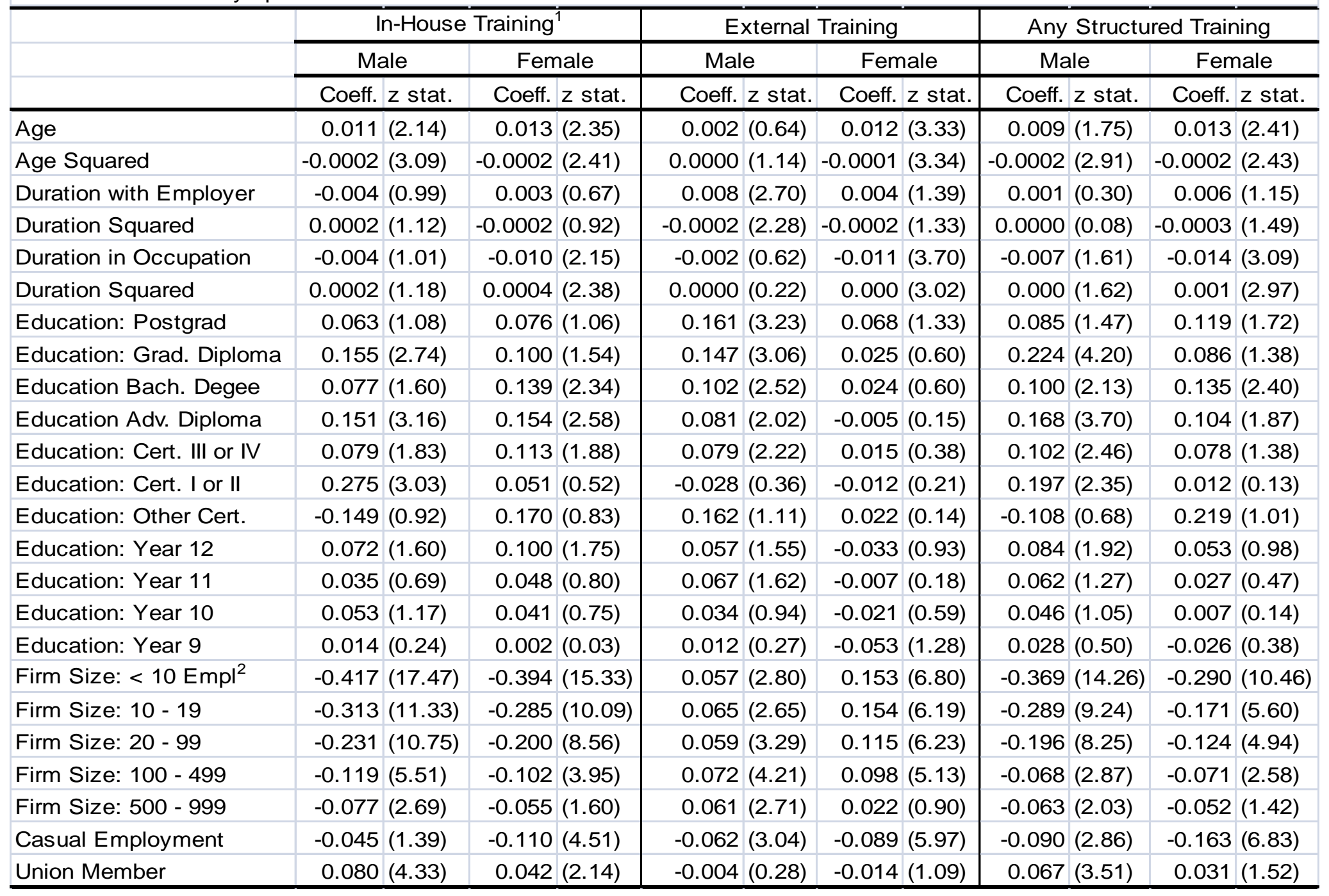


Appendix Table 2 cont. The Impact of Firm Size on the Probability of Structured Training in the last 12 Months (Marginal Effects): Absolute Value of Asymptotic z Statistic in Parentheses

\begin{tabular}{|c|c|c|c|c|c|c|c|c|}
\hline & \multicolumn{2}{|c|}{ In-House Training $^{1}$} & \multicolumn{2}{|c|}{ External Training } & \multicolumn{4}{|c|}{ Any Structured Training } \\
\hline & Male & Female & Male & Female & $\mathrm{Me}$ & ale & Fem & nale \\
\hline & Coeff. z stat. & Coeff. z stat. & Coeff. z stat. & Coeff. z stat. & Coeff. & z stat. & Coeff. & z stat. \\
\hline Public Sector Empl & $0.054(1.89)$ & $0.066(2.53)$ & $-0.044(2.31)$ & $-0.009(0.55)$ & 0.020 & $(0.65)$ & 0.043 & $(1.60)$ \\
\hline Part-Time Empl & $0.001(0.04)$ & $-0.043(2.17)$ & $-0.067(3.06)$ & $-0.079(6.56)$ & -0.042 & $(1.24)$ & -0.081 & $(4.16)$ \\
\hline Married & 0.067 (3.67) & $0.001(0.07)$ & 0.025 (2.02) & $0.016(1.38)$ & 0.088 & $(4.68)$ & 0.011 & $(0.58)$ \\
\hline Disabled & $-0.001(0.07)$ & $0.060(2.89)$ & $0.011(0.87)$ & $0.002(0.17)$ & 0.001 & $(0.06)$ & 0.070 & $(3.36)$ \\
\hline Born Eng. Speaking Ctry. & $0.012(0.50)$ & $-0.005(0.19)$ & $0.008(0.46)$ & $0.007(0.41)$ & 0.015 & $(0.61)$ & -0.008 & $(0.29)$ \\
\hline Born in Non-Eng. Spking & $-0.079(3.28)$ & $-0.104(4.02)$ & $-0.011(0.66)$ & $-0.039(2.50)$ & -0.078 & $(3.17)$ & -0.127 & $(4.86)$ \\
\hline Region: Victoria & $0.003(0.14)$ & $0.041(1.62)$ & $0.023(1.41)$ & $0.026(1.56)$ & 0.019 & $(0.78)$ & 0.048 & $(1.94)$ \\
\hline Region: Queensland & $0.053(2.11)$ & 0.070 (2.67) & $0.013(0.75)$ & $0.009(0.50)$ & 0.053 & $(2.11)$ & 0.058 & $(2.22)$ \\
\hline Region: South Aus & $0.025(0.90)$ & 0.131 (4.32) & 0.024 (1.23) & $0.007(0.36)$ & 0.023 & $(0.84)$ & 0.119 & $(4.07)$ \\
\hline Region: Western Aus & $0.059(2.20)$ & $0.078(2.77)$ & $0.046(2.43)$ & $0.027(1.47)$ & 0.079 & $(2.97)$ & 0.078 & $(2.85)$ \\
\hline Region: Other & $0.031(1.12)$ & $0.086(3.00)$ & $0.036(1.92)$ & $0.061(3.16)$ & 0.058 & $(2.11)$ & 0.139 & $(4.93)$ \\
\hline Occupation: Professional & $-0.054(1.74)$ & $-0.019(0.39)$ & $0.012(0.64)$ & $0.014(0.48)$ & -0.037 & $(1.12)$ & 0.022 & $(0.44)$ \\
\hline Occupation: Para-Prof. & $-0.035(1.06)$ & $-0.052(1.02)$ & $-0.023(1.20)$ & $-0.037(1.35)$ & -0.032 & $(0.93)$ & -0.028 & $(0.51)$ \\
\hline Occupation: Trade & $-0.095(2.81)$ & $0.013(0.19)$ & $-0.089(4.60)$ & $-0.078(2.30)$ & -0.162 & $(4.61)$ & -0.047 & $(0.65)$ \\
\hline Occupation Adv. Clerical & $-0.044(0.57)$ & $-0.121(2.19)$ & $-0.046(0.97)$ & $-0.050(1.70)$ & -0.079 & $(0.95)$ & -0.092 & $(1.57)$ \\
\hline Occupation: Inter. Clerical & $0.006(0.17)$ & $-0.045(0.91)$ & $-0.057(2.78)$ & $-0.050(1.83)$ & -0.026 & $(0.70)$ & -0.042 & $(0.81)$ \\
\hline Occupation: Prod./Transp. & $-0.104(3.00)$ & $-0.142(2.08)$ & $-0.103(5.35)$ & $-0.075(1.90)$ & -0.181 & $(5.00)$ & -0.167 & $(2.32)$ \\
\hline Occupation Elem. Clerical & $-0.123(2.83)$ & $-0.026(0.47)$ & $-0.077(2.95)$ & $-0.048(1.55)$ & -0.174 & $(3.79)$ & -0.033 & $(0.57)$ \\
\hline Occupation: Labourer & $-0.176(4.57)$ & $-0.154(2.70)$ & $-0.106(4.79)$ & $-0.099(3.46)$ & -0.261 & $(6.55)$ & -0.206 & $(3.41)$ \\
\hline Industry: Agriculture & $0.103(1.66)$ & $-0.076(0.67)$ & $0.116(2.78)$ & $0.011(0.15)$ & 0.156 & $(2.92)$ & -0.117 & $(1.01)$ \\
\hline Industry: Mining & $0.241(4.27)$ & $0.035(0.29)$ & $0.033(0.83)$ & $0.072(0.88)$ & 0.206 & $(3.80)$ & 0.145 & $(1.24)$ \\
\hline Industry: Utilities & $0.192(2.81)$ & $0.245(1.47)$ & $0.132(2.57)$ & $0.224(1.98)$ & 0.196 & $(2.89)$ & 0.371 & (2.38) \\
\hline Industry: Construction & $0.059(1.59)$ & $-0.114(1.08)$ & $0.035(1.38)$ & $0.015(0.26)$ & 0.071 & $(2.03)$ & -0.072 & $(0.75)$ \\
\hline Industry: Accomodation & $0.053(1.11)$ & $-0.040(0.78)$ & $-0.017(0.49)$ & $-0.037(1.13)$ & 0.005 & $(0.10)$ & -0.054 & $(1.08)$ \\
\hline Industry: Wholesale Trade & $0.069(1.84)$ & $-0.044(0.76)$ & $0.048(1.84)$ & $-0.025(0.74)$ & 0.105 & $(2.90)$ & -0.026 & $(0.47)$ \\
\hline
\end{tabular}


Appendix Table 2 cont. The Impact of Firm Size on the Probability of Structured Training in the last 12 Months (Marginal Effects): Absolute Value of Asymptotic z Statistic in Parentheses

\begin{tabular}{|c|c|c|c|c|c|c|}
\hline & \multicolumn{2}{|c|}{ In-House Training ${ }^{1}$} & \multicolumn{2}{|c|}{ External Training } & \multicolumn{2}{|c|}{ Any Structured Training } \\
\hline & Male & Female & Male & Female & Male & Female \\
\hline & Coeff. z stat. & Coeff. z stat. & Coeff. z stat. & Coeff. z stat. & Coeff. z stat. & Coeff. $z$ stat. \\
\hline Industry: Retail Trade & $0.054(1.68)$ & $0.017(0.40)$ & $0.006(0.29)$ & $-0.023(0.82)$ & $0.066(2.14)$ & $0.019(0.47)$ \\
\hline Industry: Transportation & $0.064(1.75)$ & $0.009(0.16)$ & $0.049(1.79)$ & $0.019(0.48)$ & $0.075(2.11)$ & $.035(0.60)$ \\
\hline Industry: Communication & $0.131(2.68)$ & $0.115(1.57)$ & $-0.012(0.32)$ & $-0.059(1.30)$ & $0.133(2.70)$ & $0.103(1.40)$ \\
\hline Industry: Finance & $0.217(4.57)$ & $0.204(4.26)$ & $0.028(0.87)$ & $-0.023(0.73)$ & $0.196(4.15)$ & $0.172(3.77)$ \\
\hline Industry: Property & $0.059(1.72)$ & $0.025(0.59)$ & $0.010(0.44)$ & $0.008(0.28)$ & $0.072(2.19)$ & $0.035(0.84)$ \\
\hline Industry: Government & $0.149(3.49)$ & $0.109(2.11)$ & $0.098(3.00)$ & $0.095(2.50)$ & $0.175(4.13)$ & $0.173(3.44)$ \\
\hline Industry: Education & 0.175 (3.92) & $0.139(3.12)$ & $0.062(1.97)$ & $0.039(1.26)$ & $0.200(4.60)$ & $0.154(3.59)$ \\
\hline Industry: Health & $0.010(0.22)$ & $0.117(2.93)$ & $0.062(1.85)$ & $0.073(2.53)$ & $0.075(1.64)$ & $0.150(3.94)$ \\
\hline Industry: Culture & $0.111(2.06)$ & $0.001(0.02)$ & $0.058(1.44)$ & $0.073(1.66)$ & $0.124(2.36)$ & $0.074(1.21)$ \\
\hline Industry: Personal Serv. & $0.166(3.57)$ & $0.088(1.61)$ & $-0.005(0.16)$ & $0.024(0.65)$ & $0.161(3.51)$ & $0.109(2.16)$ \\
\hline
\end{tabular}

Source: The data used to generate the estimates were obtained from the Survey of Education and Training, 2001 gathered by the Australian Bureau of Statistics. Excluded are respondents with no earnings, the self employed, those who did not know their employer size, students, and those who have been with their employers for less than one year.

${ }^{1}$ Independent variables are defined as the probability that a worker reported at least one internal training course, external training course, or any structured training in the previous 12 months.

${ }^{2}$ The variable for employer size is the number of employees in all the employers' establishments throughout Australia. 